\title{
EFFECT OF BIO- AND MINERAL PHOSPHORUS FERTILIZATION ON THE PRODUCTIVITY AND NUTRITIONAL VALUE OF CANOLA PLANT (BRASSICA NAPUS L.) GROWN IN A NEWLY RECLAIMED SOIL Osman, E. A. M., K. A. Khatab, and U. S. El-Bialy Soils, water and Environ. Res. Inst., Agric. Res. Center (ARC), Giza, Egypt
}

\begin{abstract}
Two field experiments were carried out in two successive winter seasons of $2006 / 2007$ and 2007/2008 to study the effect of bio-and mineral phosphorus fertilization on the yield and nutritional value of canola plant grown in calcareous soil at El -Areish Agricultural Research station, (ARC) North Sinai Governorate. The main results were as the following:

superphosphate and rock phosphate achieved a similar and insignificant effect on most measured yield characteristics, seed yield, N, P, K, oil, protein contents and oil yield in both growth seasons.

Inoculation with either mycorrhiza or Bacillus megatherium alone or Bacillus megatherium + mycorrhiza were significantly resulted in actions on most canola tested parameters compared to the treatment of without inoculation. However, seed yield and $\mathrm{P}$ percentage did not respond significantly toward the inoculation with the investigated biofertilizers in first season.

Generally the highest values obtained. for most characteristics of canola plants under investigation were achieved when the plants received rather rock phosphate or superphosphate mineral fertilizers together with mycorrhiza and/or Bacillus megatherium + mycorrhiza. While, there were insignificant differences due to their interaction on No. of branches / plant, seed yield and P percentage as well as canola plant height both in the first and second seasons.

Keywords: Canola plant (Brassica napus, L.), Bacillus megatherium, mycorrhiz, rock phosphate, superphosphate and new reclaimed soil.
\end{abstract}

\section{INTRODUCTION}

Recently, canola is considered a new oil seed crop in the newly reclaimed areas in Egypt due to a great shortage in edible oils, and large amounts are imported annually from abroad. Canola, as a winter crop can play an important role to partially cover or reduce this shortage. There is a growing need to understand the effect of bio-and mineral phosphorus fertilizers on canola plant growth, development, yield, and seed quality especially in the newly reclaimed soils. So, increasing yield of canola requires improved agricultural practices, i.e., chemical and natural phosphorus fertilization with or without inoculation with phosphate dissolving bacteria or mycorrhiza to achieve higher seed and oil yields.

Phosphorus (P) fertilization is an important input for producing canola. Phosphate-solubilizing microorganisms are abundant in the soil and may be readily isolated from a plant's rhizosphere (Kucey, 1983). Consequently, the potential use of such microorganisms as inoculants with 
rock phosphates to increase its $\mathrm{P}$-availability to plants has been studied intensively (Laheurte and Berthelin, 1988 and IIImer et al., 1995). Phosphatesolubilizing bacilli have received considerable attention as inoculants for crops. For example, Gaind and Gaur (1991) reported that a B. subtilis inoculant increased biomass, grain yield, and $\mathrm{P}$ and $\mathrm{N}$-uptake of mung bean grown in a P-deficient field soil amended with rock phosphate. This study assessed the potential use of P-solubilizing bacilli and other rhizobacteria as biofertilizers for canola crop. Use of "biofertilizers" on crops such as canola is attractive because of recent increases in seeded acreage in Canada and high cash crop value. Bacillus spp. agents were emphasized because they are some of the most abundant soil bacteria capable of solubilizing $P$, and also because they offer unique characteristics (e.g. stress-resistant spores), which may be appropriated for seed inoculants. Chabot et al. (1993) reported that $\mathrm{P}$-solubilizing-hormone-producing organism increases $\mathrm{P}$ use efficiency and crop yields. Although the exact mechanism(s) by which P-solubilizing rhizobacteria stimulate plant growth remains unclear, it does not diminish the potential use of these organisms as biofertilizers. Results also, demonstrate the potential use of these P-solubilizing-hormone-producing bacteria as inoculants for canola plants, and support observations by others that $P$ solubilization is not the explanation for growth enhancement by such bacteria. De Freitas et al. (1996) suggested that the bacilli inoculants increased the growth but not $\mathrm{P}$ nutrition of canola, this assumed that plant response to these bacteria could be associated with plant growth hormones, rather than by direct $\mathrm{P}$ solubilization action. Microbially produced plant growth regulators have been suggested as one mechanism of plant growth promotion by other P-solubilizing rhizobacteria. Brennan and Bolland (2001) reported that yield of canola increased as P rate increased. Ahmed and El-Abagy (2007) concluded that the application of bio-P fertilizer named Bacillus megatherium in two doses increased significantly growth parameters of faba bean plants at 90 and 105 days age and yield and its components as well as nutrients uptake as compared with one dose and control (without bio-P fertilizer) treatments. Tao et al. (2008) suggested that the microorganisms, which are capable of solubilizing and mineralizing phosphorus $(\mathrm{P})$ pools in soils, are considered vital in promoting $\mathrm{P}$ bioavailability.

The objective of this study is to quantify the effect of bio and mineral phosphorus application on winter canola plant survival and its crop yield.

\section{MATERIALS AND METHODS}

Two field experiments were carried out in newly cultivated calcareous soil at El -Areish Agricultural Research station, North Sinai Governorate, during the two successive winter seasons of 2006/2007 and 2007/2008 to study the effect of bio- and mineral phosphorus fertilization on the yield and nutritional value of canola plant (Brassica napus L.). Each experiment included eight treatments, which were a combination of two sources of phosphorus fertilizers, i.e., single superphosphate (SP) and rock phosphate(RP) at the rate of $15.5 \mathrm{~kg} \mathrm{P}_{2} \mathrm{O}_{5} / \mathrm{fed}$. with four inoculation of the 
bio-fertilizers, i.e., without inoculation, Phosphate dissolving bacteria (Bacillus megatherium), mycorrhiza, and Bacillus megatherium + mycorrhiza . The treatments were arranged in a split plot design with four replicates, where phosphorus sources were distributed in the main plots, while inoculation was occupied the sub-plots. The experimental unit was $21 \mathrm{~m}^{2}$ (1/200 fad.) and consisted of seven ridges, five meter in length and $60 \mathrm{~cm}$ apart. Bacillus megatherium var- phosphaticum and /or mycorrhiza were kindly supplied by the Dept. of Microbiol., Soils, Water and Environ. Inst. ( ARC), Giza, Egypt. Seeds of canola variety Sero 4 (Brassica napus L.) were obtained from Agriculture Research Centre, Ministry of Agriculture, and planted at the rate of $50 \mathrm{~kg} / \mathrm{fed} .20 \mathrm{~cm}$ between hills on November $16^{\text {th }}$ and $20^{\text {th }}$ in 2006 and 2007, respectively. Physical and chemical analyses of the experimental soil are present in Tables (1 a \& 1 b).

Table (1 a): Some physical and chemical properties of the studied soils

\begin{tabular}{|l|c|c|c|c|c|c|c|c|}
\hline \multirow{2}{*}{ Seasons } & \multirow{2}{*}{$\mathrm{pH}$} & \multirow{2}{*}{$\mathrm{*} \mathrm{EC}$} & $\mathrm{CaCO}_{3}$ & $\begin{array}{c}\mathrm{C} . \\
\text { sand }\end{array}$ & $\begin{array}{c}\mathrm{F} . \\
\text { sand }\end{array}$ & Silt & Clay & Soil \\
\cline { 4 - 9 } & & \multicolumn{6}{|c|}{$\%$} & texture \\
\hline $2006 / 2007$ & 8.40 & 2.28 & 22.80 & 27.15 & 40.40 & 31.30 & 1.15 & Sandy loam \\
\hline $2007 / 2008$ & 8.30 & 2.63 & 25.30 & 25.70 & 42.57 & 30.73 & 1.00 & Sandy loam \\
\hline
\end{tabular}

*In soil paste extract

Table ( $1 \mathrm{~b})$ :Cation and anion concentration in a paste extract of the studied soil samples together with the nutrient contents

\begin{tabular}{|c|c|c|c|c|c|c|c|c|c|c|c|}
\hline \multirow{2}{*}{ Seasons } & $\mathrm{Ca}^{++}$ & $\mathrm{Mg}^{++}$ & $\mathrm{Na}^{+}$ & $\mathrm{K}^{+}$ & $\mathrm{CO}^{-}{ }_{3}$ & $\mathrm{HCO}_{3}^{--}$ & $\mathrm{Cl}^{-}$ & $\mathrm{SO}_{4}^{-1}$ & $\mathbf{N}$ & $\mathbf{P}$ & K \\
\hline & \multicolumn{8}{|c|}{ Meq/L } & \multicolumn{3}{|c|}{ Available (ppm) } \\
\hline $2006 / 2007$ & 4.10 & 5.33 & 11.20 & 0.37 & 0.00 & 7.65 & 8.50 & 4.85 & 18.30 & 4.40 & 46.35 \\
\hline $2007 / 2008$ & 4.88 & 6.10 & 12.80 & \begin{tabular}{|l|}
0.43 \\
\end{tabular} & 0.00 & 7.21 & 10.10 & 6.90 & 19.50 & 5.80 & 49.50 \\
\hline
\end{tabular}

A basal application of $75 \mathrm{~kg} \mathrm{~N} / \mathrm{fed}$. as ammonium nitrate $(33.5 \% \mathrm{~N})$ and $48 \mathrm{~kg} \mathrm{~K} 2 \mathrm{O} / \mathrm{fed}$. as potassium sulphate $\left(48 \% \mathrm{~K}_{2} \mathrm{O}\right)$ were added in two equal split doses to all the experimental plots at 45 and 65 days after sowing. Ordinary agricultural practices were followed as recommended for canola fields.

The crop was harvested at full maturity on $5^{\text {th }}$ and $10^{\text {th }}$ of May, 2007 and 2008, respectively. Plant height $(\mathrm{cm})$, number of branches/plant, Weight of 1000-seed (g) and Seed weight /plant ( $\mathrm{g}$ ) were estimated by collecting five plants at random from each treatment. Seed yield $(\mathrm{kg} / \mathrm{fed})$ was measured and recorded. Random samples of grain representating to each replicate of all treatments were collected, oven dried, digested and assigned for analyzing $\mathrm{N}, \mathrm{P}$ and $\mathrm{K}$ contents.

Nitrogen was determined using modified Kjeldahl method, and was multiplied by $5.75 \%$ to calculate protein (\%). Phosphorous was determined colorimetrically using ammonium molybdate and ammonium metavanadate according to the procedure outlined by Ryan et al.,(1996).Potassium was determined using the flame spectrophotometry method (Black, 1982).

All obtained results were statistically analyzed using Mstat computer package to calculate $\mathrm{F}$ ratio according to Snedecor and Cochran (1980). 
Least significant differences method (L.S.D) was used to differentiate means at the 0.05 level (Waller and Duncan, 1969).

\section{RESULTES AND DISCUSSION}

\section{1-Yield and its components.}

Data presented in Tables $(2 \& 3)$ show the influence of mineral phosphorus fertilizer sources and the inoculation with or without bio-fertilizers in the form of $B$. megatherium and mycorrhiza as well as their interaction on some yield components and seed yield of canola plants grown in two successive seasons of 2006/2007 and 2007/2008. Results revealed that there was a similar and insignificant effect of superphosphate and rock phosphate on the most measured yield characteristics as well as seed yield during both growing seasons, with exception of 1000-seeds weight in the second season, when the rock phosphate increased significantly such component upon that recorded due to the application of superphosphate.

Table (2): Effect of phosphorus fertilizer source and inoculation with $B$. megatherium and /or mycorrhiza on some yield components and Seed yield of canola plants in season 2006/2007

\begin{tabular}{|c|c|c|c|c|c|}
\hline Treatments & $\begin{array}{l}\text { Plant } \\
\text { height } \\
\text { (cm) }\end{array}$ & $\begin{array}{c}\text { No of } \\
\text { branches } \\
\text { / plant }\end{array}$ & $\begin{array}{l}\text { 1000- seeds } \\
\text { Weight }(\mathrm{g})\end{array}$ & $\begin{array}{c}\text { Seed } \\
\text { weight } \\
\text { /plant (g) }\end{array}$ & $\begin{array}{c}\text { Seed } \\
\text { yield } \\
\left(\mathbf{k g} / \text { fed }^{-1} .\right)\end{array}$ \\
\hline (S P) Superphosphate & 96.75 & 5.00 & 3.81 & 24.5 & 586.87 \\
\hline (R P) Rock phosphate & 98.00 & 5.00 & 3.99 & 24.8 & 587.56 \\
\hline LSD at $5 \%$ & NS & NS & NS & NS & NS \\
\hline Without inoculation & 89.50 & 4.00 & 3.65 & 23.20 & 583.80 \\
\hline B. megatherium & 94.50 & 4.50 & 3.77 & 23.80 & 585.90 \\
\hline mycorrhiza & 103.0 & 5.50 & 4.16 & 26.00 & 590.40 \\
\hline B. megatherium + mycorrhiza & 102.5 & 6.00 & 4.03 & 25.60 & 588.90 \\
\hline LSD at $5 \%$ & 10.88 & 1.856 & 0.25 & 1.187 & NS \\
\hline (S P) Without inoculation & 92.00 & 4.00 & 3.67 & 23.40 & 585.70 \\
\hline (S P)+ B. megatherium & 96.00 & 5.00 & 3.81 & 24.00 & 587.00 \\
\hline (S P) + mycorrhiza & 98.00 & 5.00 & 3.94 & 25.20 & 587.50 \\
\hline 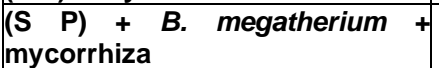 & 101.00 & 6.00 & 3.83 & 25.40 & 587.20 \\
\hline (R P) Without inoculation & 87.00 & 4.00 & 3.63 & 23.00 & 581.80 \\
\hline$(\mathrm{S} P)+$ B. megatherium & 93.00 & 4.00 & 3.73 & 23.60 & 584.70 \\
\hline (S P) + mycorrhiza & 108.00 & 6.00 & 4.38 & 26.80 & 593.30 \\
\hline $\begin{array}{l}(\mathrm{S} \\
\text { mycorrhiza }\end{array}$ & 104.00 & 6.00 & 4.22 & 25.80 & 590.50 \\
\hline LSD at $5 \%$ & 15.38 & NS & 0.35 & 1.68 & NS \\
\hline
\end{tabular}

Regarding the effect of inoculation with $B$. megatherium and / or mycorrhiza and their combination ( $B$. megatherium + mycorrhiza), data revealed that various trends occurred during the first and second seasons with similarities in some results. In the first season, inoculation with mycorrhiza alone or together with $B$. megatherium affected and positively significantly 1000-seeds weight and seed weight/plant compared to the treatments received no inoculation or inoculated with $B$. megatherium only. In addition, the positive significant effect of inoculation with $B$. megatherium + 
mycorrhiza was more pronounced on No. of branches / plant in comparison with the other treatments, which were the same to some extent. Results also indicated that the seed yield of canola plant did not respond significantly toward the inoculation with the investigated biofertilizers.

In the second season, the inoculation with mycorrhiza and/or $B$. megatherium + mycorrhiza had a positive significant effect on No. of branches / plant and 1000-seed weight compared to the treatment of without inoculation. Moreover, with regard to seed weight /plant, the inoculation with mycorrhiza was the most significant and surpassed the other tested treatments. The opposite trend was observed for the seed yield during the second season, whereas, the inoculation with either mycorrhiza or $B$. megatherium + mycorrhiza achieved significantly higher seed yield than $B$. megatherium alone or without inoculation.

Due to the interaction between mineral phosphorus fertilizer sources and the inoculation with or without such bio-fertilizers, generally, the best treatments, which achieved the highest values of canola plant characteristics, were occurred when the plants received either rock phosphate or superphosphate in addition to the inoculation with mycorrhiza and/ or $B$. megatherium + mycorrhiza. The recorded results may be due to the encouraging role of mycorrhiza or $B$. megatherium + mycorrhiza, which increases solubility of phosphate released from both rock phosphate and superphosphate. On the other hand, the results revealed that there were insignificant differences due to the interacted treatments on No. of branches / plant and seed yield of canola in the first season.

Table (3): Effect of phosphorus fertilizer source and inoculation with $B$. megatherium and/or mycorrhiza on some yield components and Seed yield of canola plants in the season 2007/2008

\begin{tabular}{|c|c|c|c|c|c|}
\hline Treatments & $\begin{array}{l}\text { Plant } \\
\text { height } \\
\text { (cm) }\end{array}$ & $\begin{array}{c}\text { No of } \\
\text { branches/ } \\
\text { plant }\end{array}$ & $\begin{array}{l}1000- \\
\text { seeds } \\
\text { Weight } \\
\text { (g) }\end{array}$ & $\begin{array}{l}\text { Seed } \\
\text { weight } \\
\text { /plant } \\
\text { (g) }\end{array}$ & $\begin{array}{l}\text { Seed yield } \\
\left(^{\left(k g / \text { fed }^{-1} .\right)}\right.\end{array}$ \\
\hline (S P) Superphosphate & 105.25 & 6.50 & 4.03 & 26.719 & 612.00 \\
\hline (R P) Rock phosphate & 106.25 & 6.50 & $4.15^{*}$ & 27.150 & 617.00 \\
\hline LSD at $5 \%$ & NS & NS & & NS & NS \\
\hline Without inoculation & 97.00 & 5.00 & 3.76 & 25.09 & 604.60 \\
\hline B. megatherium & 103.50 & 6.00 & 3.94 & 26.21 & 606.90 \\
\hline mycorrhiza & 111.50 & 7.00 & 4.32 & 28.51 & 623.70 \\
\hline B. megatherium + mycorrhiza & 111.00 & 7.00 & 4.34 & 27.92 & 623.10 \\
\hline LSD at $5 \%$ & NS & 1.87 & 0.27 & 2.92 & 1.59 \\
\hline (S P) Without inoculation & 101.00 & 5.00 & 3.80 & 25.40 & 606.50 \\
\hline$(\mathrm{S}$ P)+ B. megatherium & 104.00 & 6.00 & 3.97 & 26.42 & 609.00 \\
\hline (S P) + mycorrhiza & 107.00 & 7.00 & 4.11 & 27.20 & 615.00 \\
\hline (S P) + B. megatherium + mycorrhiza & 109.00 & 8.00 & 4.25 & 27.85 & 619.200 \\
\hline (R P) Without inoculation & 93.00 & 5.00 & 3.71 & 24.78 & 602.80 \\
\hline$(\mathrm{S} P)+$ B. megatherium & 103.00 & 6.00 & 3.91 & 26.00 & 604.80 \\
\hline$(\mathrm{S} P)+$ mycorrhiza & 116.00 & 8.00 & 4.53 & 29.83 & 632.50 \\
\hline (S P) + B. megatherium + mycorrhiza & 113.00 & 7.00 & 4.44 & 28.00 & 627.00 \\
\hline LSD at $5 \%$ & NS & 2.65 & 0.38 & 4.13 & 2.25 \\
\hline
\end{tabular}


Regarding the response of canola plant during the season of $2007 / 2008$ to the studied treatments, results indicated that the inoculation with B. megatherium and / or mycorrhiza as well as their interaction with phosphorus fertilizer achieved a significant increase in seed yield. The obtained results agreed with those of Abdalla et al. (2001), Abdel - Mouty et al. (2001) and Ahmed et al. (2003) who mentioned that phosphate dissolving bacteria presses the ability to bring a insoluble phosphate in to soluble forms through secreting organic acids, which lower the $\mathrm{pH}$ and bring about the dissolution of bonds forms of phosphate and render then available for growing plants.

The remarkable result could be observed; herein, that the plant height did not respond significantly to all phosphorus fertilizer sources as well as to the inoculation with mycorrhiza and $B$. megatherium.

\section{Chemical composition}

Tables (4 \& 5) show the same effect of the abovementioned treatments of both mineral phosphorus fertilizers and biological ones and their interaction effect on some nutrient contents of canola seeds throughout both tested seasons of 2006/2007 and 2007/2008. Results revealed that the phosphorus mineral fertilizers under study did not affect significantly N, P, K, oil and protein percentages as well as oil yield, with exception of oil percentage in the season of 2006/2007, where rock phosphate addition caused significant increases in comparison to the addition of superphosphate. These results may emphasize that the rate of phosphorus released into the root zone of canola plants was rather equal regarding both superphosphate and rock phosphate fertilizers.

Table (4): Effect of phosphorus fertilizer source and inoculation with B. megatherium and/or mycorrhiza on macronutrients, oil and Protein contents as well as oil yield of canola seeds in the season of $2006 / 2007$

\begin{tabular}{|l|c|c|c|c|c|c|}
\hline Treatments & $\begin{array}{c}\mathbf{N} \\
\%\end{array}$ & $\begin{array}{c}\mathbf{P} \\
\%\end{array}$ & $\begin{array}{c}\text { K } \\
\%\end{array}$ & $\begin{array}{c}\text { Oil } \\
\%\end{array}$ & $\begin{array}{c}\text { Oil } \\
\text { yield (kg/ } \\
\text { fed.) }\end{array}$ & $\begin{array}{c}\text { Protein } \\
\%\end{array}$ \\
\hline (S P) Superphosphate & 3.01 & 0.37 & 2.20 & 41.87 & 245.71 & 18.81 \\
\hline R P) Rock phosphate & 3.02 & 0.38 & 2.25 & $42.10^{\star}$ & 246.45 & 18.95 \\
\hline LSD at 5\% & NS & NS & NS & & NS & NS \\
\hline Without inoculation & 2.84 & 0.33 & 2.06 & 40.72 & 238.4 & 17.75 \\
\hline B. megatherium & 2.96 & 0.37 & 2.23 & 41.53 & 243.3 & 18.52 \\
\hline mycorrhiza & 3.12 & 0.40 & 2.27 & 42.80 & 250.8 & 19.50 \\
\hline B. megatherium + mycorrhiza & 3.16 & 0.41 & 2.35 & 42.75 & 251.9 & 19.75 \\
\hline LSD at 5\% & 0.20 & NS & 0.22 & 01.06 & 7.873 & 1.218 \\
\hline (S P) Without inoculation & 2.87 & 0.33 & 2.07 & 40.75 & 240.1 & 17.94 \\
\hline S P)+ B. megatherium & 2.96 & 0.38 & 2.24 & 41.85 & 245.7 & 18.50 \\
\hline S P) + mycorrhiza & 3.02 & 0.36 & 2.13 & 42.22 & 248.1 & 18.88 \\
\hline (S P) + B. megatherium + mycorrhiza & 3.19 & 0.41 & 2.36 & 42.40 & 249.0 & 19.94 \\
\hline R P) Without inoculation & 2.81 & 0.32 & 2.04 & 40.70 & 236.7 & 17.56 \\
\hline (S P)+ B. megatherium & 2.97 & 0.36 & 2.22 & 41.20 & 240.9 & 18.54 \\
\hline S P) + mycorrhiza & 3.22 & 0.44 & 2.41 & 43.38 & 253.4 & 20.13 \\
\hline $\begin{array}{l}\text { (S P) + B. megatherium } \\
\text { mycorrhiza }\end{array}$ & 3.13 & 0.41 & 2.33 & 43.10 & 254.7 & 19.56 \\
\hline LSD at 5\% & & & & & & 1.72 \\
\hline
\end{tabular}


Data in Table (5) showed that there was a clear and significant difference between the treatments of $B$. megatherium, mycorrhiza and their mixture (B. megatherium + mycorrhiza), as compared with the control treatment (without inoculation) during the both tested seasons. Mostly, the inoculation with $B$. megatherium + mycorrhiza produced the highest $\mathrm{N}, \mathrm{P}, \mathrm{K}$ and oil contents, as well as the protein constituents of canola seeds. This result goes along with the fact that inoculation with either mycorrhiza alone or (B. megatherium + mycorrhiza) together has a great importance in the availability of phosphorus in the soil. These results agree with those obtained by Ahmed and El-Abagy (2007).

Table (5): Effect of phosphorus fertilizer source and inoculation with $B$. megatherium and/or mycorrhiza on macronutrients, oil and Protein contents as well as oil yield of canola seed in the season of $2007 / 2008$

\begin{tabular}{|c|c|c|c|c|c|c|}
\hline Treatments & $\begin{array}{l}\mathbf{N} \\
\%\end{array}$ & $\begin{array}{l}\mathbf{P} \\
\%\end{array}$ & $\begin{array}{l}\mathbf{K} \\
\%\end{array}$ & $\begin{array}{l}\text { Oil } \\
\%\end{array}$ & \begin{tabular}{|l} 
Oil yield \\
$(\mathrm{kg} /$ fed.)
\end{tabular} & Protein \% \\
\hline (S P) Superphosphate & 3.10 & 0.39 & 2.25 & 40.73 & 249.51 & 19.36 \\
\hline (R P) Rock phosphate & 3.08 & 0.41 & 2.30 & 41.00 & 253.02 & 19.22 \\
\hline LSD at $5 \%$ & NS & NS & NS & NS & NS & NS \\
\hline Without inoculation & 2.91 & 0.34 & 2.09 & 39.32 & 237.7 & 18.19 \\
\hline B. megatherium & 3.02 & 0.39 & 2.29 & 40.57 & 246.2 & 18.88 \\
\hline mycorrhiza & 3.21 & 0.43 & 2.33 & 41.78 & 260.6 & 20.06 \\
\hline B. megatherium + mycorrhiza & 3.22 & 0.43 & 2.40 & 41.81 & 260.5 & 20.13 \\
\hline LSD at $5 \%$ & 0.20 & 0.87 & 0.18 & 1.75 & 11.39 & 1.26 \\
\hline (S P) Without inoculation & 2.95 & 0.35 & 2.10 & 39.32 & 238.4 & 18.44 \\
\hline$(\mathrm{S} P)+$ B. megatherium & 3.05 & 0.40 & 2.30 & 40.55 & 247.0 & 19.06 \\
\hline (S P) + mycorrhiza & 3.12 & 0.38 & 2.17 & 41.40 & 254.6 & 19.50 \\
\hline 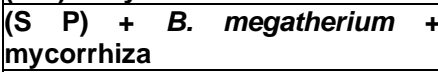 & 3.27 & 0.44 & 2.43 & 41.65 & 258.0 & 20.44 \\
\hline (R P) Without inoculation & 2.87 & 0.33 & 2.07 & 39.31 & 236.9 & 17.94 \\
\hline$(\mathrm{S}$ P)+ B. megatherium & 2.98 & 0.38 & 2.28 & 40.60 & 245.4 & 18.63 \\
\hline (S P) + mycorrhiza & 3.29 & 0.48 & 2.48 & 42.15 & 266.6 & 20.56 \\
\hline 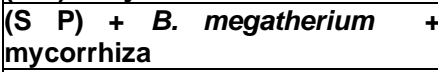 & 3.16 & 0.43 & 2.37 & 41.96 & 263.1 & 19.75 \\
\hline LSD at $5 \%$ & 0.29 & 0.12 & 0.26 & 2.48 & 16.11 & 1.78 \\
\hline
\end{tabular}

With regard to the interaction between factors under study on some chemical composition of canola seeds, data presented in Tables (4 \& 5) showed that the percentages of $\mathrm{N}, \mathrm{P}, \mathrm{K}$, oil and protein as well as the values of oil seeds yield were more pronounced as a result of inoculation with either mycorrhiza or $B$. megatherium accompanied with rock phosphate and/or superphosphate as mineral forms. In addition, results showed that the positive significant effect of the interacted treatments appeared sharply in both seasons. Furthermore, the best results of the chemical composition of canola seeds were obtained under the interacted treatments of rock phosphate and/or superphosphate with inoculation of either mycorrhiza or $B$. megatherium + mycorrhiza in both growing seasons.

From the abovementioned results and according to the logical science, it can be stated the beneficial role of biofertilizers in increasing the 
solubility and availability of phosphorus in the soil to compensate the needs of this element to the plants. Results of bio-P- fertilizer in this study are in agreement with those obtained by Chabot et al. (1993) who attributed the positive growth promotion of maize inoculated with P-solubilizing pseudomonas and Enterobacter spp. to the ability of such bacteria to solubilize P and produce siderophores and auxins. Also, El-Sheekh (1997) concluded that the application of $B$. megatherium increased plant growth and dry matter of onion due to such bacterial agent enhanced phosphorous solubilization in soil. In addition, El-Karamany et al. (2000) stated that the effect of bio-fertilizer may be due to the effect of nutrients mobilizing microorganisms, which help in the availability of metals and increased their extractable amounts.

It can be concluded that using rook phosphate as a natural phosphate source instead of the artificial superphosphate in the presence of either mycorrhiza or $B$. megatherium + mycorrhiza can increase the quantity and quality of canola yield and may decline the hazard of some contaminated heavy metals accompanied with superphosphate fertilizer.

\section{REFERENCES}

Abdalla, A. M., F. A. Rizk and S. M. Adam (2001). The productivity of pepper plants as influenced by some bio-fertilizer treatments under plastic house conditions. Bull. Fac. Agric. Cairo Univ., 52: 625.

Abdel-Mouty, M. M., A. H. All and F. A. Rizk (2001). Potato yield as affected by the interaction between bio-and organic fertilizers. Egypt. J. Appl. Sci., 16: 267.

Ahmed, M. A. and H. M. H. El-Abagy (2007). Effect of bio- and mineral phosphorus fertilizer on the growth, productivity and nutritional value of some faba bean (Vicia faba L.) cultivars in newly cultivated land. J. of Appl. Sci. Res., 3: 408-420.

Ahmed, M. K. A., H. M. Afifi and M. F. Mohamed (2003). Effect of biofertilizer, chemical and organic fertilizers on growth, yield and quality of some leguminous crops. Egypt. J. Agron., 25: 45-52.

Black, C. A. (1982). Methods of soil analysis. Part 2. Chemical and microbiological properties. Second Edition. Amer. Soc. of Agron. Madison, Wisconsin, U.S. A.

Brennan, R. F., and M. D. A. Bolland (2001). Comparing fertilizer phosphorus requirements of canola, lupin, and wheat. J. Plant Nut., 24:1885-1900.

Chabot, R., H. Antoun and M. P. Cescas (1993). Stimulation de la croissance du mais et de la laitue romaine par des microorganismes dissolvent de phosphore inorganique. Can. J. Microbiol., 39:941-947.

De Freitas, J. R., M. R. Banerjee and J. J. Germida (1996).

Phosphate-solubilizing rhizobacteria enhance the growth and yield but not phosphorus uptake of canola (Brassica napus L.) Biol. Fertil. Soils 24:358-364.

El-Karamany, M. F., M. K. Ahmed, A. A. Bahr and M. O. Kabesh (2000). Utilization of biofertilizers in field crop production. Egypt. J. Appl. Sci., 15: 137. 
El-Sheekh, H. M. (1997). Effect of bio- and mineral phosphate fertilizers on growth, yield and storability of onion. Egypt. J. Appl. Sci., 12:213.

Gaind, S. and A. C. Gaur (1991). Thermotolerant phosphate solubilizing microorganisms and their interaction with mung bean. Plant and Soil. 133:141-149.

IIImer, P., A. Barbato and F. Schinner (1995). Solubilization of hardly-soluble $\mathrm{AlPO}_{4}$ with P-solubilizing microorganisms. Soil Biol. Biochem., 27:265270.

Kucey, R. M. N. (1983). Phosphate-solubilizing bacteria and fungi in various cultivated and virgin Alberta soils. Can. J. Soil Sci., 63:671-678.

Laheurte, F. and J. Berthelin (1988). Effect of a phosphate-solubilizing bacteria on maize growth and root exudation over four levels of labile phosphorus. Plant and Soil. 105:11-17.

Ryan, J., S. Garabet, K. Harmsen and A. Rashid (1996). A soil and plant Analysis Manual Adapted for the West Asia and North Africa Region. ICARDA, Aleppo, Syria. 140pp.

Snedecor, G. W. and W. G. Cochran (1980). One way classification-Analysis of Variance - The random effect model- Two way Classification (Eds.) In Statistical Methods. The lowa State Univ. Press Ames lowa USA, 215-273.

Tao, G. C., S. J. Tian, M. Y. Cai, and G. H. Xie (2008). Phosphate-solubilizing and -mineralizing abilities of bacteria isolated from soils. Pedosphere. 18(4): 515-523.

Waller, R. A. and C. B. Duncan (1969). Abays rule for symmetric multiple comparison problem Amer. State Assoc. Jour. December: 1485-1503.

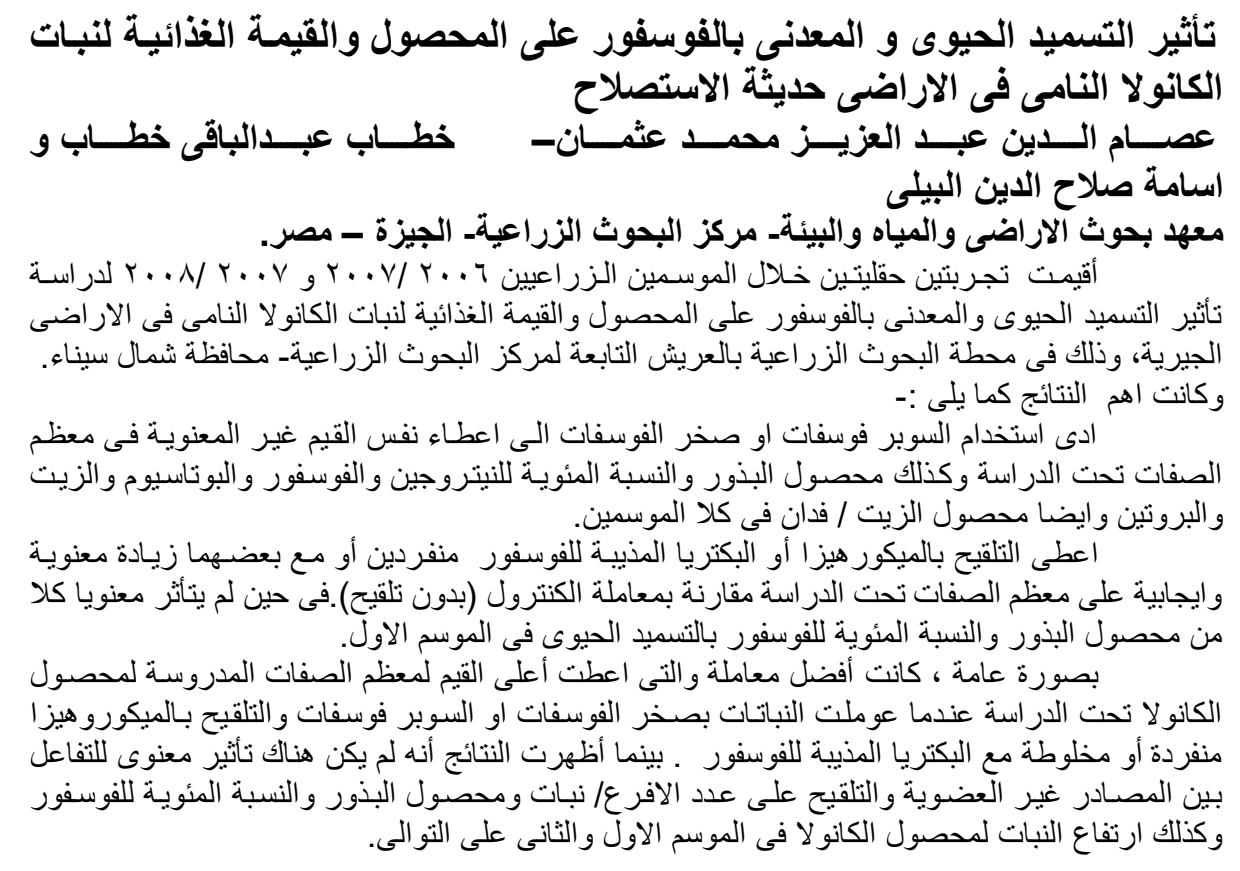

